\title{
EDITORIAL
}

\section{Reflexão crítica, prática da interdisciplinaridade, pesquisa em acervos}

Em tempos de constantes ataques à ciência, ao serviço público e ao patrimônio público, os textos que compõem este número reafirmam a missão de "promover uma reflexão crítica sobre o Brasil, a partir da prática da interdisciplinaridade e da pesquisa em acervos", do Instituto de Estudos Brasileiros (20I8, p. 2). Trata-se de um conjunto variado, característica que decorre da avaliação de artigos em fluxo contínuo, no qual se inscrevem algumas das linhas de força do pensamento contemporâneo na área de Humanidades.

"As caravanas: racismo e novo racismo", de Adélia Bezerra de Meneses (USP), articula diversos instrumentos da crítica literária a fim de examinar, em profundidade e com viés ensaístico, os sentidos históricos que se encapsulam nos versos de uma canção de Chico Buarque lançada em 20I7. Um deles, a permanência e o recalque do passado escravocrata no presente da zona sul do Rio de Janeiro, mas valendo metonimicamente por um retrato atual do Brasil. A seguir, "Braços nas argolas e sorrisos nos rostos: narrativas museais sobre a escravidão”, de Vinícius Oliveira Pereira (UERJ) e Alexandra Lima da Silva (UERJ), analisa imagens de acervos de museus brasileiros disponíveis na internet, assim como postagens em redes sociais, e discute, dentre outros temas, "a insistência por parte das instituições museais em valorizar a dimensão da violência cometida contra escravizados" e "a desvinculação entre trauma e racismo", seguindo uma pista teórica apontada por Grada Kilomba.

Novamente em perspectiva ensaística, "Modos de conexão popular no cinema brasileiro pré-64: Considerações sobre Vidas secas, Os fuzis e o inacabado Cabra marcado para morrer", de Paulo Toledo Bio (UFRJ), investiga três exemplos da tentativa de estabelecer laços "com as frações populares e marginais do país" naquele período. Com diferentes resultados, essa intenção dos artistas se refletiu "no nível temático, estético, político e também produtivo das obras", e seu apagamento nas realizações mais recentes e nos debates, segundo o autor, nos daria prova das fraturas que passaram a enformar a sociedade brasileira desde o golpe de I964. Ainda na esfera do cinema, mas em junção com os campos literário e historiográfico, "Do dois ao três, ou A reprodução da burrice paulista", de Victor Santos Vigneron (USP), empreende uma criteriosa revisão bibliográfica e se ampara em pesquisa no precioso acervo da Cinemateca Brasileira para analisar a adaptação cinematográfica de Amar, verbo intransitivo - romance 
de Mário de Andrade, publicado em I927 - por Paulo Emílio Salles Gomes, ao final dos anos I960.

Parte da obra epistolar de Mário de Andrade e de sua fortuna crítica é analisada em "Cartas para Murilo Miranda, o amigo com quem envelheço", artigo de Monica Gomes da Silva (UFRB) e Matildes Demétrio dos Santos (UFF). O trabalho enfatiza de que modo impasses como o embate entre o funcionalismo público e a atividade artística se refletiram em uma escrita que "transgride os limites convencionais do gênero [...], pelo seu valor literário e histórico”. Já “Literatura e Filosofia em Raul Pompeia”, de Marconi Severo (UFSM), se alia à crítica da recepção daquele escritor por seus contemporâneos e, analisando as técnicas composicionais empregadas em Canções sem metro, à revisão da estética de Pompeia que se desenvolve nos últimos decênios.

Radicado no estudo da arquitetura brasileira, mas em chave interdisciplinar, "O Iberismo como primitivismo: a abordagem de José Marianno Filho", de Ana Paula Koury (USJT), pesquisa artigos publicados na década de I920, n’O Jornal, com a hipótese de que neles Marianno Filho incluiu a "herança ibérica como parte de um programa nacionalista, em sintonia com o quadro político do Brasil republicano", acabando por fornecer elementos fundamentais para a "narrativa nacionalista do modernismo". Recuando no tempo, "Teatralidade e carnavalização. Zé Pereira no final do séc. XIX”, de Marcelo Fecunde de Faria (UFG) e Robson Corrêa de Camargo (UFG), examina "crônicas de Vieira Fazenda (I847-I9I7) e de Luís Edmundo de Melo Pereira da Costa (I878-I96I)" e busca compreender "a criação do personagem Zé Pereira" em meio a um período de "mudanças radicais" no Brasil e, sobretudo, no Rio de Janeiro, período do qual fez parte "o processo de higienização das festas de ruas". Encerrando a seção, "Entre Ciência e História: Brasil, um Jardim para a França”, de Ana Beatriz Demarchi Barel (UEG), estuda relações entre romances de José de Alencar e relatos de viagem de Ferdinand Denis e de Auguste de Saint-Hilaire.

Na seção seguinte, Criação, são publicados três Contos baldios de Márcio Marciano. Dramaturgo e encenador, Marciano foi um dos fundadores da Companhia do Latão em São Paulo, em I997, e do Coletivo de Teatro Alfenim em João Pessoa, em 2007. Seu trabalho artístico, para o crítico José Antonio Pasta (20I7, p. 22), "tem o vezo de procurar resolver os problemas, não ao aliviá-los, obviando o que neles é obstáculo, mas, ao contrário, incrementando a sua dificuldade, extremando-a, até que ela passe no seu outro”.

$\mathrm{Na}$ seção Documentação, o artigo "Quando 'restos mortais' tornam-se rastros: algumas reflexões sobre a organização do Fundo Alice Piffer Canabrava do Arquivo do Instituto de Estudos Brasileiros da Universidade de São Paulo (IEB/USP)", de Otávio Erbereli Júnior (USP), reúne a narrativa “da operação arquivística" a uma série de reflexões que resultam de "um convívio quase diário, por dois anos, com a documentação". Por fim, a resenha "Primeira República e Era Vargas. Reflexões para a compreensão da atualidade”, de Fábio Alexandre dos Santos (Unifesp), analisa e interpreta História Econômica do Brasil. Primeira República e Era Vargas, obra organizada por Guilherme Grandi e 
Rogério Naques Faleiros, segundo volume da Coleção Novos Estudos em História Econômica do Brasil.

As imagens desta RIEB remarcam que chegamos à edição de número 80. $\mathrm{Na}$ antessala do aniversário de 60 anos do instituto, a mirada histórica se perfaz também nas demais imagens, que registram as três edificações que se sucederam enquanto sede do IEB. A dimensão histórica está também na representação de trabalhadoras e trabalhadores, que empregaram a sua "corporalidade” (QUIJANO, 20Io) no cotidiano do instituto. A dimensão estética da sede atual deseja esperançar, no sentido freireano (FREIRE, I996), um presente-futuro, em que espaço e corpo se encontram, nas atividades coletivas que seguem desenhando a instituição e sua missão.

Há quase 40 anos, em I982, Roberto Schwarz (I987, p. 85) observava que "a riqueza da vida cultural nasce do confronto de posições, que no Brasil anda frouxo”. Se é certo dizer que hoje esse confronto se fortaleceu ao se rebaixar, então, esperamos que este número colabore para a vida cultural fundada na reflexão crítica e na pesquisa científica. Boa leitura!

\section{Inês Gouveia' ${ }^{1}$ Luciana Suarez Galvão², Walter Garcia ${ }^{3}$ \\ Editores}

\section{Referências}

FREIRE, Paulo. Pedagogia da autonomia: Saberes necessários à prática educativa. 20 ed. São Paulo: Paz e Terra, I996.

INSTITUTO DE ESTUDOS BRASILEIROS. Projeto acadêmico. Instituto de Estudos Brasileiros, Universidade de São Paulo, 20I8. Disponível em: http://www.ieb.usp.br/wp-content/uploads/sites/I27/20I9/og/ Projeto-acad\%C3\%AAmico-Aprovado-CD_29.II.20I8.pdf. Acesso em: I2 nov. 202I.

PASTA, José Antonio. Dialética do Alfenim - nota crítica e teórica. In: CABRAL, Adriano; MARCIANO, Márcio; COELHO, Paula. Memórias de um cão: caderno de Apontamentos. João Pessoa: Coletivo de Teatro Alfenim, 20I7, p. 2I-29.

QUIJANO, Anibal. Colonialidade do poder e classificação social. In: SANTOS, Boaventura de Sousa e MENEZES, Maria Paula. Epistemologias do Sul. São Paulo: Cortez, 2010.

SCHWARZ, Roberto. Política e cultura. In: SCHWARZ, Roberto. Que horas são?: ensaios. São Paulo: Companhia das Letras, I987, p. 83-85. 


\section{SOBRE OS AUTORES}

INÊS GOUVEIA é docente do Instituto de Estudos Brasileiros da Universidade de São Paulo (IEB/USP). inescgouveia@usp.br https://orcid.org/o0oo-0003-4783-9033

LUCIANA SUAREZ GALVÃO é docente do Instituto de Estudos Brasileiros da Universidade de São Paulo (IEB/USP).

lsgalvao@usp.br

https://orcid.org/0000-0003-I369-688X

WALTER GARCIA é docente do Instituto de Estudos Brasileiros da Universidade de São Paulo (IEB/USP). waltergarcia@usp.br https://orcid.org/o0o0-0002-0455-483I

Recebido em I2 de novembro de $202 \mathrm{I}$

Aprovado em I9 de novembro de $202 \mathrm{I}$

GOUVEIA, Inês; GALVÃO, Luciana Suarez; GARCIA, Walter. Reflexão crítica, prática da interdisciplinaridade, pesquisa em acervos. Revista do Instituto de Estudos Brasileiros, Brasil, n. 80, p. I3-I6, dez. 202I.

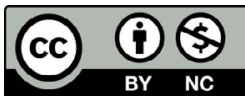

DOI: https://doi.org/Io.II606/issn.23I6-90IX.vii8opI3-I6 